\title{
PENENTUAN EFISIENSI INHIBISI REAKSI KOROSI BAJA MENGGUNAKAN EKSTRAK KULIT BUAH MANGGIS (Garcinia mangostana L)
}

\author{
Yuli Rizky Ananda Nasution, Sri Hermawan, Rosdanelli Hasibuan \\ Departemen Teknik Kimia, Fakultas Teknik, Universitas Sumatera Utara, \\ Jl. Almamater Kampus USU Medan 20155, Indonesia \\ Email: reaz_ky@students.ac.id
}

\begin{abstract}
Abstrak
Ekstrak kulit buah manggis merupakan inhibitor alami yang dapat digunakan untuk menghambat laju reaksi korosi. Penelitian diawali dengan mengekstraksi kulit buah manggis dengan cara maserasi kemudian dilanjutkan dengan evaporasi dan hasil ekstrak digunakan sebagai inhibitor dengan konsentrasi 600, 800 dan 1000 ppm, dengan sampel uji korosi yaitu baja dengan ukuran $1 \times 2 \mathrm{~cm}$ dengan ketebalan 0,1 cm dan media korosif air laut, air hujan dan asam sulfat 1M. Efisiensi inhibisi tertinggi yang dihasilkan adalah 99,22\%, dengan pelarut etanol pada konsentrasi inhibitor 800 ppm dalam media korosif air hujan; yang berarti bahwa ekstrak kulit buah manggis lebih efisien digunakan pada media korosif air hujan.
\end{abstract}

Kata kunci: manggis, media korosif, laju korosi, efisiensi inhibisi

\begin{abstract}
Garcinia mangostana peel extract is a natural inhibitor that can be used to inhibit the corrosion reaction rate. This research begins by extracting Garcinia Mangostana pods by maceration followed by evaporation and extracts used as the inhibitor with concentration 600, 800 and $1000 \mathrm{ppm}$, with the test sample of corrosion is steel $1 \times 2 \mathrm{~cm}$ with the thickness is $0,1 \mathrm{~cm}$ and corrosive medias are sea water, rain water and sulfuric acid $1 \mathrm{M}$. The highest inhibition efficiency generated is $99,22 \%$ with ethanol solvent at concentration of 800 ppm inhibitor in rain water corrosive media; which means that Garcinia mangostana peel extract more efficiently used in rain water corrosive media.
\end{abstract}

Keywords: garcinia mangostana, corrosive media,reaction rate, inhibition efficiency

\section{Pendahuluan}

Korosi adalah degradasi atau penurunan mutu logam akibat reaksi kimia suatu logam dengan lingkungannya [6]. Korosi merupakan masalah besar bagi peralatan yang menggunakan material dasar logam seperti mobil, jembatan, mesin, pipa, kapal dan lain sebagainya [8]. Dampak yang dapat ditimbulkan akibat kerusakan oleh korosi akan sangat besar pengaruhnya terhadap kehidupan manusia, antara lain dari segi ekonomi dan lingkungan. Dari segi ekonomi misalnya tingginya biaya perawatan, tingginya biaya bahan bakar dan energi akibat kebocoran uap, kerugian produksi pada suatu industri akibat adanya pekerjaan yang terhenti pada waktu perbaikan bahan yang terserang korosi, dan dari segi lingkungan misalnya adanya proses pengkaratan besi yang berasal dari berbagai konstruksi yang dapat mencemarkan lingkungan [11]. Beberapa cara yang dapat memperlambat laju reaksi korosi antara lain dengan cara pelapisan permukaan logam agar terpisah dari media korosif, membuat paduan logam sehingga tahan korosi, dan dengan penambahan zat tertentu yang berfungsi sebagai inhibitor reaksi korosi. Hal ini yang menyebabkan penggunaan kulit buah manggis sebagai inhibitor reaksi korosi yang ramah lingkungan. Perumusan masalah dalam penelitian ini adalah bagaimana pengaruh penambahan ekstrak kulit buah manggis terhadap laju reaksi korosi pada baja dan bagaimana efisiensi inhibisi ekstrak kulit buah manggis pada berbagai media korosif. Tujuan dari penelitian ini adalah untuk menghasilkan ekstrak kulit buah manggis yang mengandung tanin dan mengetahui efisiensi inhibisi tertinggi dari ekstrak kulit buah manggis.

\section{Teori}

Manggis merupakan tanaman buah yang berasal dari hutan tropis yang teduh di kawasan Asia Tenggara, yaitu hutan belantara Malaysia atau Indonesia. Buah manggis merupakan spesies terbaik dari genus Garcinia dan mengandung gula sakarosa, dekstrosa dan levulosa. Kulit buah manggis dimanfaatkan untuk menyamak kulit dan sebagai zat warna hitam untuk makanan dan industri tekstil, sedangkan getah kuningnya dimanfaatkan sebagai bahan baku cat dan insektisida. Selain itu air rebusan kulit buah manggis memiliki efek antidiare. Senyawa yang 
terkandung dalam kulit buah manggis adalah xanthone yang meliputi mangostin, mangosterol, mangostinon-A, mangostinon-B, trapezifolixanton, tovophyllin-B, alfa dan beta mangostin, garcinon$\mathrm{B}$, mangostanol, falvonoid epikatekin, dan gartanin Senyawa tersebut sangat bermanfaat untuk kesehatan [7]. Kulit manggis mengandung air $5,87 \%$, abu $2,17 \%$, lemak $6,45 \%$, protein $3,02 \%$, gula $2,10 \%$, karbohidrat $68,50 \%$, tanin $13,98 \%$, antosianin 5,7-6,2 mg/g, xanton 0,7-34,9 mg/g dan total fenol 50,5-154,6 mg/g [3].

Tanin merupakan komponen zat organik derivat polimer glikosida yang terdapat dalam bermacam-macam tumbuhan, terutama tumbuhan berkeping dua (dikotil). Monomer tanin adalah digallic acid dan D-glukosa dan memiliki rumus molekul $\mathrm{C}_{76} \mathrm{H}_{52} \mathrm{O}_{46}$. Ekstrak tanin terdiri dari campuran senyawa polifenol yang sangat kompleks dan biasanya tergabung dengan karbohidrat rendah. Oleh karena adanya gugus fenol, maka tanin akan dapat berkondensasi dengan formaldehida. Tanin terkondensasi sangat reaktif terhadap formaldehida dan mampu membentuk produk kondensasi, berguna untuk bahan perekat termosetting yang tahan air dan panas [12].

Maserasi merupakan proses perendaman sampel menggunakan pelarut organik pada temperatur ruangan. Proses ini sangat menguntungkan dalam isolasi senyawa bahan alam karena dengan perendaman sampel tumbuhan akan terjadi pemecahan dinding dan membran sel akibat perbedaan tekanan antara di dalam dan di luar sel, sehingga metabolit sekunder yang ada dalam sitoplasma akan terlarut dalam pelarut organik dan ekstraksi senyawa akan sempurna karena dapat diatur lama perendaman yang dilakukan [1].

Korosi adalah kerusakan atau degradasi logam akibat reaksi dengan lingkungan yang korosif. Adapun beberapa cara dalam pengendalian proses yaitu dengan metode pelapisan, dengan proteksi katodik dan dengan penambahan [2].

\section{Metodologi Penelitian \\ Bahan dan Alat}

Bahan yang digunakan adalah kulit buah manggis sebagai bahan baku, sebagai zat pengekstrak digunakan etanol $70 \%$, baja $1 \times 2 \mathrm{~cm}$ dengan ketebalan $0,1 \mathrm{~cm}$ sebagai sampel uji korosi, media korosif menggunakan asam sulfat $1 \mathrm{M}$, air laut dan air hujan, sebagai indikator tanin digunakan larutan $\mathrm{FeCl}_{3}$ 1\%. Alat utama yang digunakan adalah rotary vacuum evaporator untuk proses evaporasi.

\section{Proses Pembuatan Serbuk Kulit Buah Manggis}

Kulit buah manggis dibersihkan dari kotorankotoran, kemudian dirajang kecil-kecil dan dikeringkan di udara terbuka selam 3 hari. Kulit yang telah kering digiling hingga menjadi serbuk.

\section{Proses Ekstraksi}

Serbuk kulit buah manggis sebanyak 100 gr dimasukkan ke dalam maserator, kemudian dimasukkan etanol $70 \%$ sebanyak 1 L. Kemudian campuran diaduk dan dibiarkan di dalam maserator selama 120 jam, hasil maserasi disaring dengan menggunakan kertas saring, kemudian filtratnya dimasukkan ke dalam rotary vacuum evaporator pada suhu $54-55^{\circ} \mathrm{C}$ selam 1 jam. Hasil ekstraknya dimasukkan ke dalam botol coklat dan dilakukan analisa kualitatif apakah terdapat tanin.

\section{Analisa Kualitatif}

Ekstrak kulit buah manggis sebanyak $10 \mathrm{gr}$ dimasukkan ke dalam beaker glass, kemudian ditambahkan air $10 \mathrm{ml}$ dan dipanaskan hingga mendidih. Setelah itu disaring dan diambil filtratnya, kemudian filtratnya ditambahkan $\mathrm{FeCl}_{3}$ $1 \%$ sebanyak 10 tetes, jika berubah warna menjadi biri atau biru kehijauan maka terdapat tanin.

\section{Persiapan Baja yang Akan di uji}

Sampel baja dengan ukuran 1 x $2 \mathrm{~cm}$ dengan tebal $0,1 \mathrm{~cm}$ dihaluskan permukaannya dengan ampelas. Permukaan yang telah halus ini dicuci dengan deterjen, dan aquades, kemudian dikeringkan dalam oven pada suhu $110^{\circ} \mathrm{C}$ selama 2 jam.

\section{Perendaman Baja dalam Larutan Media Korosif Tanpa Penambahan Inhibitor}

Sampel baja yang telah disiapkan masingmasing direndam dalam media korosif yaitu air laut, air hujan dan asam sulfat $1 \mathrm{M}$ selama 120 jam.

\section{Perendaman Baja dalam Larutan Media Korosif dengan Penambahan Inhibitor}

Sampel baja yang telah disiapkan masingmasing direndam dalam larutan campuran media korosif dan inhibitor selama 120 jam. Variasi konsentrasi inhibitor adalah 600, 800 dan 1000 ppm. Kemudian ditentukan laju reaksi korosi dan efisiensi inhibisi dengan menggunakan persamaan 1 dan persamaan 2 .

\section{Penentuan Laju Reaksi Korosi}

Setelah proses korosi berjalan selama 120 jam, produk korosi diangkat dari media korosi, dicuci dengan menggunakan sikat yang halus. Selanjutnya dikeringkan pada suhu kamar, kemudian ditimbang sebagai berat akhir. Berat awal dari baja adalah berat baja sebelum direndam kedalam larutan. Laju reaksi korosi dihitung dengan rumus berikut : 
Laju Reaksi Korosi $=\frac{\text { Berat Awal }- \text { Berat Akhir }}{\text { Luas Baja } \times \text { Waktu Perendaman }}$ (1)

\section{Penentuan Efisiensi Inhibisi}

Efisiensi Inhibisi $=\frac{\text { Vko }- \text { Vki }}{\text { Vko }} \times 100 \%$

Dimana : $\mathrm{V}_{\mathrm{ko}}=$ laju reaksi korosi tanpa inhibitor $\mathrm{V}_{\mathrm{ki}}=$ laju reaksi korosi dengan inhibitor

\section{Hasil dan Pembahasan}

Laju reaksi korosi baja tanpa penambahan inhibitor pada media korosif air laut sebesar $0,0387 \mathrm{mg} / \mathrm{cm}^{2}$.jam, pada media korosif air hujan sebesar $0,0235 \mathrm{mg} / \mathrm{cm}^{2}$.jam dan pada media korosif asam sulfat $1 \mathrm{M}$ sebesar 1,3692 $\mathrm{mg} / \mathrm{cm}^{2}$.jam.

\section{Hubungan Laju Korosi - Konsentrasi Inhibitor}

Hubungan laju korosi terhadap konsentrasi inhibitor dapat dilihat pada gambar 1, dimana laju reaksi korosi yang diperoleh cenderung menurun untuk setiap kenaikan konsentrasi inhibitor.

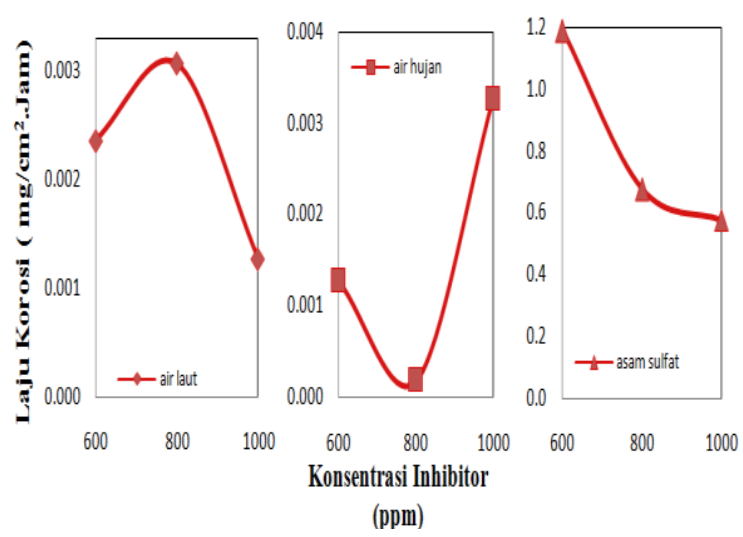

Gambar 1. Laju Reaksi Korosi Berdasarkan Konsentrasi Inhibitor

Laju reaksi korosi dengan adanya ekstrak kulit buah manggis dalam air laut, air hujan maupun asam sulfat menurun jika dibandingkan dengan tanpa penambahan ekstrak. Hal ini disebabkan karena adanya senyawa tanin yang ada dalam ekstrak yang dapat membentuk senyawa kompleks dengan Fe(III) di permukaan logam [5], sehingga laju reaksi korosi akan mengalami penurunan. Senyawa kompleks ini akan menghalangi serangan ion-ion korosif pada permukaan logam, sehingga laju reaksi korosi akan menurun. Laju reaksi korosi tertinggi mencapai $1,19 \mathrm{mg} / \mathrm{cm}^{2}$.jam pada media korosif asam sulfat dengan konsentrasi inhibitor 600 ppm, dan laju reaksi korosi terendah mencapai 0,000181 $\mathrm{mg} / \mathrm{cm}^{2}$.jam pada media korosif air hujan dengan konsentrasi inhibitor $800 \mathrm{ppm}$. Pada grafik terdapat titik yang mengalami kenaikan yaitu dalam media korosif air laut pada konsentrasi inhibitor 800 ppm dan air hujan pada konsentrasi inhibitor $1000 \mathrm{ppm}$, hal ini disebabkan karena lapisan Fe-tanin ekstrak tidak bisa menutupi seluruh permukaan baja, sehingga pada bagian yang tidak tertutupi Fe dapat terion dan mengalami korosi. Selain itu, ada pengotor-pengotor pada ekstrak tanin yang menempel pada permukaan baja juga mempengaruhi cepatnya korosi [4]. Dengan demikian ekstrak kulit buah manggis dapat menghambat laju korosi baja sehingga dapat dijadikan sebagai inhibitor dalam reaksi korosi pada baja.

\section{Hubungan Efisiensi Inhibisi - Konsentrasi Inhibitor}

Hubungan efisiensi inhibisi terhadap konsentrasi inhibitor dapat dilihat pada gambar 2, dimana efisiensi inhibisi cenderung menaik untuk setiap penambahan konsentrasi inhibitor.
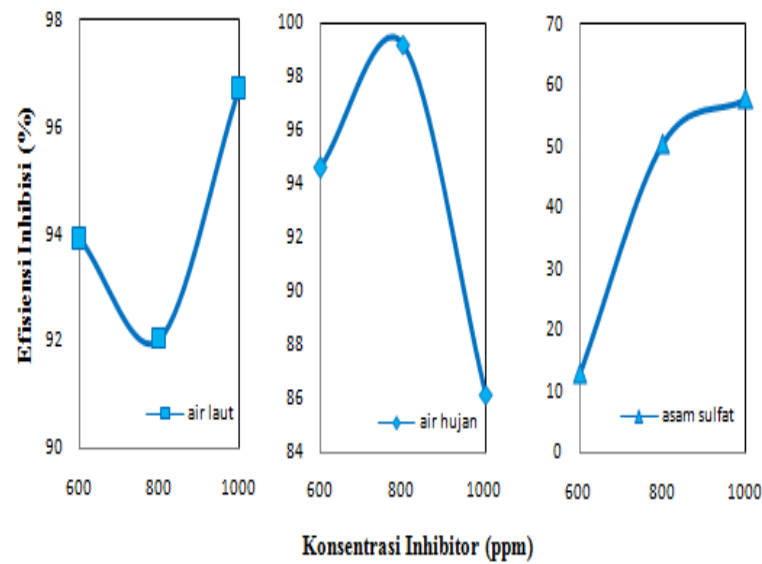

\section{Gambar 2. Efisiensi Inhibisi Berdasarkan Konsentrasi Inhibitor}

Efisiensi inhibisi ekstrak kulit buah manggis yang dihasilkan berbeda-beda tergantung pada konsentrasi inhibitor dan media korosif. Pada grafik dapat dilihat bahwa efisiensi inhibisi pada media korosif air laut dapat mencapai $96,72 \%$ pada konsentrasi inhibitor $1000 \mathrm{ppm}$, efisiensi inhibisi pada media korosif air hujan dapat mencapai 99,22\% pada konsentrasi inhibitor 800 ppm, efisiensi inhibisi pada media korosif asam sulfat dapat mencapai $57,78 \%$ pada konsentrasi inhibitor $1000 \mathrm{ppm}$. Efisiensi inhibisi tertinggi yang dihasilkan adalah pada media korosif air hujan dengan konsentrasi inhibitor 800 ppm, hal ini disebabkan karena pada kondisi tersebut senyawa kompleks Fe-tanin terbentuk dengan sempurna dan menutupi seluruh permukaan baja. Sedangkan efisiensi terendah pada media korosif asam sulfat. Hal ini disebabkan karena asam sulfat bereaksi dengan senyawa tanin, sehingga mengurangi kinerja tanin untuk melapisi permukaan baja. Asam sulfat dapat bereaksi dengan tanin 
disebabkan kandungan tanin pada Manggis tergolong pada tanin ellagitanin. Ellagitanin merupakan jenis tanin yang terhidrolisis. Hidrolisis dengan asam kuat akan menghasilkan asam ellagat [9], seperti yang ditunjukkan pada gambar 3 .
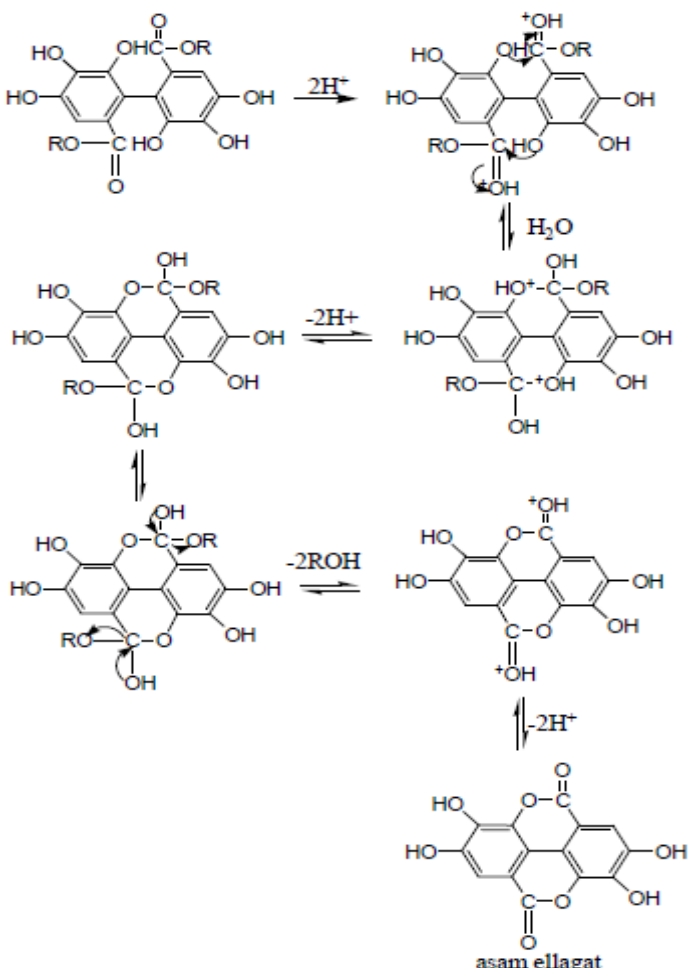

Gambar 3. Reaksi hidrolisis ellagitanin [10].

Tanin kulit buah manggis bereaksi dengan asam sulfat sehingga membentuk asam ellagat, sehingga tidak dapat menutupi permukaan baja secara keseluruhan.

\section{Kesimpulan}

Kulit buah manggis dapat menghambat laju reaksi korosi pada baja, sehingga dapat dijadikan sebagai inhibitor alami dalam reaksi korosi.

Laju korosi menurun dengan bertambahnya konsentrasi inhibitor (ekstrak kulit buah manggis).

Efisiensi inhibisi tertinggi terjadi pada media korosif air hujan dengan konsentrasi inhibitor 800 ppm yaitu sebesar 99,22\%. Sedangkan efisiensi terendah pada media korosif asam sulfat dengan konsentrasi inhibitor 600 ppm sebesar 13,08\%.

\section{Daftar Pustaka}

[1] Asep W. Permana, Kulit Buah Manggis dapat menjadi Minuman Instan Kaya Antioksidan, Jurnal Pascapanen Pertanian, Volume 32 No. 2, Balai Besar Penelitian dan Pengembangan Pascapanen Pertanian, Bogor, 2010.

[2] Budiyanto, Pengendalian Korosi, Budisma.blogspot.com, 2011, diakses tanggal 02 Juli 2012.

[3] Efri Mardawati, Kajian Aktivitas Antioksidan Ekstrak Kulit Manggis (Garcinia Mangostana L ) dalam Rangka Pemanfaatan Limbah Kulit Manggis di Kecamatan Puspahiang Kabupaten Tasikmalaya, Laporan Akhir Penelitian, Universitas Padjadjaran, Bandung, 2008.

[4] Emriadi, Mekanisme dan Laju Reaksi Inhibisi Korosi Baja Oleh Tanin, Universitas Andalas, Sumatera Barat, 2000.

[5] Favre, The Influence of Gallic Acid On The Reduction of Rust on Painted Steel Surface, J. Corrosion Science 34, (1993) 1483-1492.

[6] Priest. D, Measuring Corrosion Rates Fast. J. Chemical Engineering, vol : 2 no. 1 (1992) 169-172.

[7] Qosim. W A, Kulit Buah Manggis Sebagai Antioksidan. www. pikiranrakyat. com, 2007, diakses pada 03 Agustus 2012.

[8] Rieger, Electrochemistr, 2nd ed. Chapman and Hall Inc. New York, 1992, p. 412-421.

[9] S. Bate, Detection And Determinant of Ellagitannin Phytochemistry and International Journal Of Plant Biochemistry Vol II, England: Pragaman Press, 1972.

[10] Solomons G.T., Organic Chemistry, 4 th ed, John Wiley and Sons, New York, 1976, p. 838-839.

[11] Trethewey dan Chamberlin, Korosi ed.1, Gramedia Pustaka Utama, Jakarta, 1991, p. 69-70.

[12] Westendarp, Effects of tannins in animalnutrition. Dtsch. Tierarztl, Wochensch, 2006, p. 264-268. 